\title{
TRANSLATION TECHNIQUES WITHIN FOREIGNIZATION STRATEGY FOR RENDERING LEXICAL UNITS OF DIFFERENT THEMATIC GROUPS IN AMERICAN UNIVERSITY DISCOURSE
}

\section{ПЕРЕКЛАДАЦЬКІ ПРИЙОМИ ВІДТВОРЕННЯ ЛЕКСИЧНИХ ОДИНИЦЬ РІЗНИХ ТЕМАТИЧНИХ ГРУП У МЕЖАХ СТРАТЕГІЇ ФОРЕНІЗАЦІЇ В АМЕРИКАНСЬКОМУ УНІВЕРСИТЕТСЬКОМУ ДИСКУРСІ}

\author{
Masanovets V.Yu., \\ orcid.org/0000-0002-6498-1560 \\ Assistant Professor at the Department of Theory and Practice of Translation from English \\ Taras Shevchenko National University of Kyiv
}

The article aims at establishing the correlation between the translation strategy of foreignization and specific translation techniques in rendering various thematic groups of lexical units in American university discourse based on the novel The Secret History by Donna Tartt (2014) and its Ukrainian translation by Bohdan Stasiuk (2017). The notions of foreignization translation strategy and translation techniques have been studied. The notion of American university discourse is defined as texts with specific formal and semantic features that reflect social reality in the context of the American university. The author employs a comparative, contextual and translation analyses of the source and target texts. The empirical material of the research comprises one hundred lexical units foreignized in the TT. The study singles out the following thematic groups of lexical units foreignized in the TT: 1) personal and geographical names (35\%) and honorifics (3\%); 2$)$ foreign inclusions (21\%); 3) names of companies, institutions and facilities $(20 \%)$; 4 ) names of newspapers and magazines and titles of books (9\%); 5) musical pieces, songs and bands (7\%); 6) food and drink brands (5\%). A specific translation technique prevailing in each group of foreignized units is determined. According to the findings of the research, pure or naturalized borrowing and pure borrowing with amplification (in the form of footnotes and additional information in the text) are the main translation techniques used when rendering lexical units from all the groups. The results show that the translator of the novel tends to balance foreignised elements with additional lexical units, explanations and descriptions.

Key words: foreignization translation strategy, translation techniques, American university discourse, pure borrowing, naturalised borrowing, amplification.

Стаття присвячена встановленню співвідношення між перекладацькою стратегією форенізації та перекладацькими прийомами у разі відтворення різних тематичних груп лексичних одиниць в американському університетському дискурсі на матеріалі роману Донни Тартт «Таємна історія» (2014) та його українського перекладу, виконаного Богданом Стасюком (2017). Проаналізовано поняття перекладацької стратегії форенізації та перекладацьких прийомів. Американський університетський дискурс визначено як тексти, пов'язані особливими формальними і семантичними рисами, що відображають соціальну дійсність у контексті американського університету. У дослідженні використано компаративний, контекстуальний та перекладацький аналіз тексту оригіналу (TO) та тексту перекладу (ТП). Емпіричним матеріалом слугує сто відібраних лексичних одиниць, щодо яких була застосована стратегія форенізації у ТП. Виокремлено такі групи форенізованої лексики: 1) імена людей та географфічні назви $(35 \%)$ і гоноративи (3\%); 2) іншомовні вкраплення $(21 \%) ; 3)$ назви компаній та установ $(20 \%)$; 4) назви газет, журналів та книг (9\%); 5) назви музичних гуртів, назви і тексти пісень (7\%); 6) бренди їжі та напоїв (5\%). У кожній категорії форенізованих лексичних одиниць визначено перекладацькі прийоми їх відтворення. Згідно з результатами дослідження, у всіх категоріях основними прийомами перекладу лексичних одиниць є запозичення (чисте або натуралізоване) та чисте запозичення з ампліффікацією (у формі виносок та додаткової інформації безпосередньо в тексті). Аналіз матеріалу розвідки показує, що перекладач переважно урівноважує форенізовані елементи додатковими лексичними одиницями, описами та поясненнями.

Ключові слова: перекладацька стратегія форенізації, перекладацькі прийоми, американський університетський дискурс, чисте запозичення, натуралізоване запозичення, ампліфікація.

Introduction. Fiction translation imposes great challenges for the translator in terms of choosing the overall translation strategy. On the one hand, a work of art has to find its place in the target culture, become accessible to the TL-reader and impart understandable values. On the other hand, a translated work implies the presence of certain elements from the source culture and a typical TL name for a dog in a novel translated from another language may jut out in certain contexts and be confusing to the reader.
L. Venuti differentiates between two opposing translation strategies, namely domestication and foreignization [1]. According to Venuti, domestication refers to an ethnocentric reduction of the foreign text to target-language cultural values, which brings the author back home, while foreignization is an ethnodeviant pressure on cultural values to register the linguistic and cultural difference of the foreign text, sending the reader abroad $[1$, p. 20]. Consequently, domestication helps the translator to make the TT quite smooth and readable, while foreigni- 
zation preserves the required amount of strangeness of a translated text.

The idea of "translation strategy" emerged long before translation studies appeared as an academic discipline. According to H. Krings, a translation strategy is "translator's potentially conscious plans for solving concrete translation problems in the framework of a concrete translation task" [2, p. 264]. W. Loescher defines translation strategy as "a potentially conscious procedure for solving a problem faced in translating a text, or any segment of it" [3, p. 8]. The present research follows L. Venuti' definition of translation strategies who indicates that translation strategies "involve the basic tasks of choosing the foreign text to be translated and developing a method to translate it" and employs the concepts of domesticating and foreignizing to refer to translation strategies [4, p. 240].

Foreignization as a translation strategy implies deliberate violation of target conventions. L. Venuti himself favours foreignization and supports that by arguing that a translator's mission is to retain the cultural values of the source language and not manipulate it into the target language [1, p. 305]. Foreignized items stand out in the TT due to their strangeness that can be preserved by means of various translation techniques. It should be noted that there is a lack of consensus between translation scholars as to the definitions of translation strategies and translation techniques. Furthermore, different classifications have been proposed and the terms often overlap. The present research follows Lucía Molina's idea of the difference between translation strategies and translation techniques according to which "strategies open the way to finding a suitable solution for a translation unit, but the solution itself will be materialized by using a particular technique" [5, p. 508]. L. Molina's translation techniques classification serves as the foundation for analysis of the ways used to implement foreignization translation strategy in the Ukrainian translation of the novel.

This paper focuses on lexical units in American university discourse, which were foreignized in Ukrainian translation. The notion of discourse is understood as a text (speech event) in combination with extralinguistic - pragmatic, social, cultural, psychological - factors [6]. Taking into account the specifics of the material of the study, we interpret American university discourse as texts with specific formal and semantic features that reflect social reality in the context of the American university [7].

The research concentrates on the novel The Secret History (Donna Tartt, 1992) [8] and its Ukrainian (Bohdan Stasiuk, 2017) translation [9] as a vivid example of American university discourse. It is an inverted detective story and a campus novel, also known as an academic novel. The main action in the works of this genre is set in and around the campus of a university and can be characterized by a finite, enclosed space, academic terms, clear power relationships (teacher/student; tenured professor/scrabbling lecturer), etc. [10]. Tartt's debut tells the story of a closely knit group of six Classics students at a small, elite liberal arts college in Vermont, who discuss works of literature, Greek philosophy and history and have parties. The language of the novel is rich in inclusions of foreign words of Latin and Greek origin, bookish vocabulary and informal words.

Both foreignization and domestication strategies were applied in the Ukrainian translation of the novel done by Bohdan Stasiuk. Due to domestication of various lexical and phraseological units, the TT reads quite smoothly. Together with that, it contains some foreignized inclusions that preserve the ambience of the campus novel and help to render the lexical characteristics of American university discourse.

The aim ofthepresentresearchisto establish the correlation between foreignization translation strategy and the most frequently used translation techniques based on American university discourse. In order to fulfil the aim, the following objectives were set:

- to define lexical units in The Secret History by Donna Tartt which were foreignized in the Ukrainian translation of the novel done by Bohdan Stasiuk;

- to categorise the foreignized lexical units from American university discourse according to the theme, e.g., food and drinks brands, personal and geographical names, foreign inclusions, etc., in order to identify the general tendency;

- to analyse translation techniques employed in each category;

- to establish the correlation between foreignization translation strategy and translation techniques in rendering lexical units from different thematic groups in American university discourse.

In fulfilling the objectives of the study, a comparative analysis complemented by contextual, stylistic and translation analyses are applied. The main general methods of the research include induction, deduction, classification method, the method of quantitative estimate, and the continuous sampling method. The research has been conducted in several stages. At the first stage, by way of the continuous sampling method the material of the research was collected and the research methodology was worked out. At the second stage, foreignized lexical units in the TT and ST were analysed and categorised. The third stage involved contextual and translation analyses 
to identify translation techniques. At the final stage of our research, method of quantitative estimate was employed to describe the research results and establish the correlation between the translation techniques and foreignization translation strategy in the TT.

Results and Discussions. By means of continuous sampling method, 100 lexical units foreignized in the Ukrainian translation have been analysed and grouped according to the theme (e.g., personal names, geographical names, food and drink brands, etc.). The units were chosen following L. Venuti's criteria of identifying foreignized elements that stand out as alien in the TT, deliberately break target conventions and retain some foreignness of the original [1]. In the context of the material of the research, the smooth and readable flow of the TT is interrupted by lexical units of various origins written in the Latin alphabet (e.g. " "Вчора я помилково замовив Conche" (Italian), "Та задля певності я все ж постукав у двері. Pas de réponse" (French), "Я був не у Food King” (English), etc.); transcriptions of typical American personal names and geographical names (e.g., Річард Пейпен, Генрі Вінтер, Гемпден, Санта-Фе, etc.); forms of address such as мicmep, sic, etc.

The findings of the research showed that each group of lexical units is foreignized in the TT by means of several translation techniques with one translation technique prevailing. The following analysis of the material provides a detailed picture of how each lexical group is foreignized in the Ukrainian translation and what translation techniques are used.

Personal and geographical names $(35 \%)$. All the analysed units (17 personal names and 18 geographical names) are rendered into Ukrainian as naturalized borrowings: Bunny Corcoran - Банні Коркоран, Charles Macaulay - Чарльз Маколі, Judy Poovey - Джуді Пуві; Tarrytown - Tерpiтаун, New York-Нью-Йорк, Vermont-Вермонт. Transcription as a form of naturalized borrowing is used in translation of honorifics (3\%) Mr and Mrs: Mr Mac Nattмістер Мак-Hamm, Mrs Gamp - місіс Гемп, etc. The words are transcribed with Cyrillic letters to fit the requirements of the TL. Lexical units from this group acquire gender and case in the TT, but the foreignness is still retained in the very meaning of each word which is culture-specific. Moreover, the translator transcribes names of streets and avenues using the American way of writing address with the word "street" or "avenue" as part of the name: Prospect Street - Проспект-стріm, Water Street - Boтерcmpim, Park Avenuе - Парк-авеню. Although naturalized to some extent, these units immediately remind readers of the culture the novel is set in.
Food and drink brands (5\%). Five units from this group were rendered either by means of pure borrowing (e.g., three bottles of Taittinger - три пляшки Taittinger) or pure borrowings with amplification (e.g., some Vichy water-мінералка Vichy). In the first case, the unit is taken straight from the SL with no changes. Pure borrowings are not transcribed and they don't acquire any grammatical traits of the TL. In the second case, pure borrowings are amplified with additional information, which is not formulated in the ST but which is crucial for the target reader's understanding.

Additional information is often required when the meaning of a culture-specific item cannot be inferred from the immediate context, as in the examples in table 1.

For a Ukrainian reader Pop Tarts (1) can be anything eaten with coffee. It evokes no specific associations. Since details play a very important part in Donna Tartt's style of writing, the translator neither omit the name alien to the target reader, nor leaves it as it is, in the form of pure borrowing, but explains its meaning using a noun печиво. In the second example, the translator adds an adjective мелений to the word Folgers, which is a coffee brand. Moreover, in this particular dialogue, the character is disappointed that Folgers is all they have. The added adjective helps to convey this shade of meaning, since the quality of ground coffee is generally regarded as lower than that of, for example, whole bean coffee. The elite group of students do not enjoy drinking cheap coffee or cheap alcohol. All these details are important since they serve as the evidence of the group's extravagant lifestyle. In the third example, the translator renders this information by amplifying The Famous Grouse with an explanation престижна марка.

Names of newspapers and magazines and titles of books $(\mathbf{9 \%})$. The translation techniques of pure borrowing (table 2, examples 1-3) or pure borrowing with amplification (table 2, examples 4,5 ) are employed to translate the units from this category.

As a rule, it is clear from the context what each foreignized unit means. Nevertheless, in certain cases the translator resorts to amplification translation technique and adds the explanation, e.g., the word yасопис. In examples 4 and 5 (table 2) there are nouns стос and сторінках in the TT that require Genitive case from the following lexical units. By introducing additional TL units ( стос часописів, $\mu a$ сторінках часопису), the translator makes the text smoother, while retaining the foreignized elements (National Geographic, People).

Names of companies, institutions and facilities $\mathbf{( 2 0 \% )}$. In this group, the prevailing translation techniques are pure borrowing and pure borrowing with 
Techniques of pure borrowing and amplification in translation of food and drink brands

\begin{tabular}{|c|c|c|}
\hline & Eng. (Tartt, 1992) [8] & Ukr. (Tartt, 2017) [9] \\
\hline 1 & .... a silent, cheerless breakfast of coffee and Pop Tarts & $\begin{array}{l}\text {...мовчки поглинали невеселий сніданок, щцо складався } \\
\text { з кави та печива Pop Tarts. }\end{array}$ \\
\hline 2 & $\begin{array}{l}\text { 'American coffee all you have?' } \\
\text { 'What do you mean? Folger's?' }\end{array}$ & $\begin{array}{l}\text { - Кава тільки американська? } \\
\text { - Ти про що? Про мелений Folgers? }\end{array}$ \\
\hline 3 & a fifth of Famous Grouse & двохсотку престижноӥ марки Fатоиs Grouse. \\
\hline
\end{tabular}

Techniques of pure borrowing and pure borrowing with amplification in translation of names of newspapers and magazines and titles of books

\begin{tabular}{|c|l|l|}
\hline & \multicolumn{1}{|c|}{ Eng. (Tartt, 1992) [8] } & \multicolumn{1}{c|}{ Ukr. (Tartt, 2017) [9] } \\
\hline 1 & We were in House Beautiful last year & Торік про нас писали в Hоиме Beautiful \\
\hline 2 & ... a rolled-up copy of the Hampden Examiner. & $\begin{array}{l}\text {...згорнутим у трубочку примірником Hampden } \\
\text { Examiner. }\end{array}$ \\
\hline 3 & put out by the Harvard University Press. & надруковану в Harvard University Press. \\
\hline 4 & а pile of National Geographies & стос часописів National Geographic. \\
\hline 5 & ... found its way into People magazine & ...з'явився на сторінках часопису Peорle \\
\hline
\end{tabular}

Technique of pure borrowing in translation of names of companies/institutions explained by the immediate context

\begin{tabular}{|c|c|c|}
\hline & Eng. (Tartt, 1992) [8] & Ukr. (Tartt, 2017) [9] \\
\hline 1 & $\begin{array}{l}\text { 'The four of us,' he said, at last, 'were at a matinee } \\
\text { at the Orpheum in town - a double feature that ran } \\
\text { from one o'clock to four-fifty-five. }\end{array}$ & $\begin{array}{l}\text { Ми всі вчотирьох, - нарешті продовжив він, -ходили } \\
\text { в Orрhешт на спарений денний сеанс, щзо тривав із } \\
\text { першої по четверту п'ятдесят п'ять. }\end{array}$ \\
\hline 2 & $\begin{array}{l}\text { 'I know, but still, if I've learned one thing from this it } \\
\text { is never to order flowers from Sunset Florists again. } \\
\text { All the things from Tina's Flowerland are so much } \\
\text { nicer. Francis' }\end{array}$ & $\begin{array}{l}\text { Знаю. Але одну річ я засвойла дуже добре - більще } \\
\text { ніколи й нічого не замовляти в Sunset Florists. У } \\
\text { Tina's Flowerland сервіс набагато кращчии. Френсісе }\end{array}$ \\
\hline
\end{tabular}

Table 4

Technique of pure borrowing with amplification in translation of names of companies/institutions

\begin{tabular}{|l|l|l|}
\hline & \multicolumn{1}{|c|}{ Eng. (Tartt, 1992) [8] } & \multicolumn{1}{|c|}{ Ukr. (Tartt, 2017) [9] } \\
\hline 1 & $\begin{array}{l}\text { About halfway, he stopped at the dusty roadside win- } \\
\text { dow of a Tastee Freeze, across the highway from the } \\
\text { Veterans Hospital, and bought an ice-cream soda. }\end{array}$ & $\begin{array}{l}\text { Десь на півдорозі, навпроти Ветеранського шииталю, } \\
\text { він зупинвся біля віконечка придорожнньої забігай- } \\
\text { лівки Tasteе-Freеz і купив собі крем-соди. }\end{array}$ \\
\hline 2 & $\begin{array}{l}\text { Just for the hell of it, we drove by the State Liquor } \\
\text { Store. }\end{array}$ & $\begin{array}{l}\text { Абсолютно навмання ми зазирнули в алкогольний } \\
\text { супермаркет State Liquоr Store. }\end{array}$ \\
\hline
\end{tabular}

Technique of pure borrowing and amplification with footnotes in translation of musical pieces

\begin{tabular}{|c|c|c|}
\hline & , 1992) [8] & Ukr. (Tartt, 2017) [9] \\
\hline 1 & $\begin{array}{l}\text { He sits around in his room with the door } \\
\text { locked and does lines and listens to this } \\
\text { song by the Buffalo Springfield, over and } \\
\text { over... you know that one? "Something's } \\
\text { happening here... what it is ain't exactly } \\
\text { clear..." }\end{array}$ & 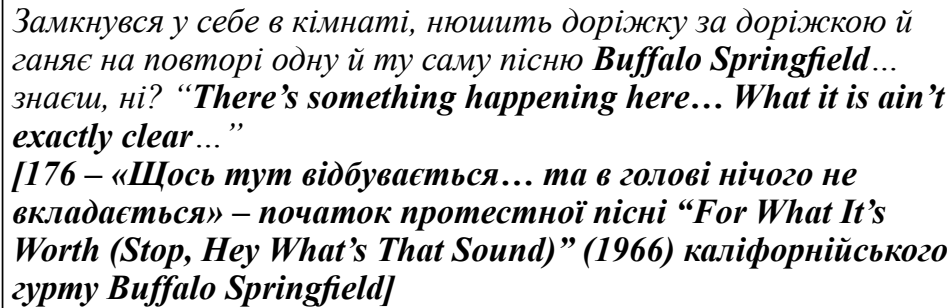 \\
\hline 2 & $\begin{array}{l}\text {...Francis was singing, as though it was the } \\
\text { happiest song in the world: "We are little } \\
\text { black sheep who have gone astray... Baa } \\
\text { baa baa..." }\end{array}$ & 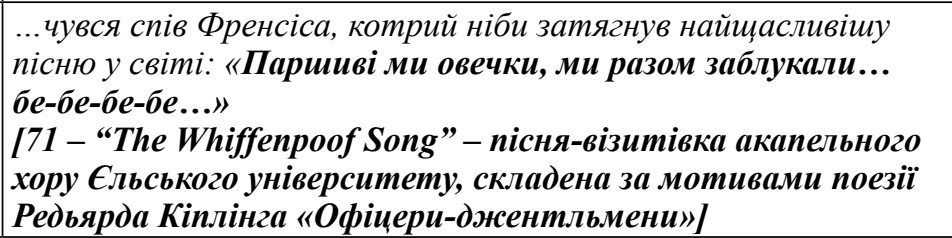 \\
\hline
\end{tabular}


Table 6

Translation of foreign inclusions

\begin{tabular}{|c|c|c|}
\hline & Eng. (Tartt, 1992) [8] & Ukr. (Tartt, 2017) [9] \\
\hline 1 & $\begin{array}{l}\text { Pur: that one word contains for me the secret, the } \\
\text { bright, terrible clarity of ancient Greek. }\end{array}$ & $\begin{array}{l}\text { Пг̃р - у цім слові для мене ховається таємниця, } \\
\text { яскрава й моторошна чистота стародавньої греки. }\end{array}$ \\
\hline 2 & $\begin{array}{l}\text { Henry inclined his head slightly. 'Bonjour, Monsieur } \\
\text { Laforgue,' he said. 'Quel plaisir de vous revoir.' }\end{array}$ & $\begin{array}{l}\text { - Bonjour, Monsieur Laforgue, -nривіmaвся він. - } \\
\text { Quel plaisir de vous revoir. } \\
\text { [169-Доброго ранку, пане Лафорт. Радий знову } \\
\text { бачити вас (фр..]. }\end{array}$ \\
\hline 3 & 'Amanita phalloides, 'said Henry mildly. 'Death cap.' & $\begin{array}{l}\text { - Amanita phalloides, - тихо відказав Генрі. - Зеленим } \\
\text { мухомором, або ж блідою поганкою. }\end{array}$ \\
\hline
\end{tabular}

amplification as well. There are several possible reasons of why the translator reproduces the units from this category in the TT unchanged. The first one is that the name of the company/institution is well-known to an average target reader, e.g., McDonald's, Food King, Burger King. The second reason is the immediate context which explains the foreignized notion (table 3 ).

The target reader is not likely to mistaken Orpheum for a restaurant or a café, since the very sentence in which it is used provides some important details such as a double feature matineе - спарений денний сеанс and its duration clearly indicating that Orpheum is the name of a theatre. In the second example, two flower shops/deliveries are compared: you can "order flowers" - "замовляти щось" in both shops, but "things from Tina's Flowerland are so much nicer" - "У Tina's Flowerland сервіс набагато краший". The context implies that it is a service that sells flowers and not a theatre or a food delivery.

In certain contexts, the translator resorts to amplification to avoid ambiguity and explicate the meaning of the unit (table 4).

In the first example, the name Tastee-Freez rendered into the TT as a pure borrowing has an amplification: придорожня забігайлівка. The second example has an amplification as well: алкогольний супермаркет which explains the very name of the store. Additional information reproduced by means of amplification translation technique helps the TL reader have the same experience as that of the SL reader without stumbling on an unknown foreign element that could mean various things.

There is one example of a partly naturalized borrowing: to Federal Express it - вiдnравити $\ddot{x}$ Federal Express' ом. The name of the world-famous cargo airline is used in its original form with a flection of a TL instrumental case to make the character sound more natural.

Musical pieces, songs and bands (7\%). The translator renders names of bands by means of pure borrowing with amplification in the form of footnotes where he gives detailed information about the band and the song (table 5).
In the first example the lyrics remain unchanged in the TT, but the footnote provides not only information about the band, its origin and the year of creation of the song, but a rhymed translation of the original lines. In the second example, the lyrics are translated in the TT to preserve the humorous effect, which otherwise would be ruined with foreign words. The information about the song is given in a footnote (amplification technique).

Foreign inclusions (21\%). As it was mentioned, American university discourse is characterized by foreign lexical inclusions. The main characters are erudite and well-read. They quote ancient philosophers by heart and use other languages (French, Italian, Latin, ancient Greek) to express complicated notions and ideas or to have fun (table 6).

Lexical units in other languages function as foreign elements in the ST as well. They are rendered into Ukrainian by means of pure borrowing with amplification in the form of footnotes (example 2) or in the text itself (example 3). In the third example, two colloquial synonyms (зелений мухомор and бліда поганка) for the Latin name (Amanita phalloides) are given to render one notion from the ST (Death cap). This clearly shows that the translator tends to balance foreignized elements with additional lexical units, explanations and descriptions.

Conclusions. The paper is focused on establishing the correlation between foreignization translation strategy and specific translation techniques in rendering various thematic groups of lexical units in American university discourse based on the novel The Secret History by Donna Tartt and its Ukrainian translation. The empirical material of the research comprises one hundred lexical units foreignized in the TT. The results of the research show that in the TT foreignization translation strategy is applied to the following thematic groups of lexical units: 1) personal and geographical names $(35 \%)$ and honorifics $(3 \%) ; 2)$ foreign inclusions $(21 \%) ; 3)$ names of companies, institutions and facilities (20\%); 4) names of newspapers and magazines and titles of books (9\%); 5) musical pieces, songs and bands 
$(7 \%)$; 6) food and drink brands $(5 \%)$. The translator tends to balance foreignized elements with additional lexical units, explanations and descriptions. The prevailing translation techniques in all thematic groups of foreignized lexical units are borrowing (pure and naturalized) and amplification (in the TT or in the form of footnotes). Prospects for further scientific research involve establishing the correlation between translation strategies of domestication and foreignization in American university discourse.

\title{
REFERENCES:
}

1. Venuti L. The Translator's Invisibility: A History of Translation. London \& New York, 1995. 352 p.

2. Krings H.P. Translation problems and translation strategies of advanced German learners of French. I J. House, \& S. Blum Kulka (Eds.), Interlingual and intercultural communication. Tubingen, 1986. Pp. 263-275.

3. Loescher W. Translation performance, translation process and translation strategies. Tuebingen : Guten Narr, 1991. $307 \mathrm{p}$.

4. Venuti L. Strategies of translation. / In M. Baker (Ed.), Encyclopedia of translation studies. London and New York, 1998. Pp. 240-244.

5. Molina L. \& Albir A. Translation Techniques Revisited: A Dynamic and Functionalist Approach. Meta: Journal des traducteurs. 47.498. 10.7202/008033ar, 2002. Pp. 498-512. URL: https://www.researchgate.net/ publication/272899204_Translation_Techniques_Revisited_A_Dynamic_and_Functionalist_Approach.

6. Arutyunova N.D. Discourse. Linguistic encyclopedic dictionary. Moscow, 1990. Pp. 136-137.

7. Parulina I.I. University Discourse: Corpus Compilation (A Case Study of the Secret History by Donna Tartt). Bulletin of the South Ural State University. Ser. Linguistics. 2016, Vol. 13, No. 2, pp. 70-74 (in Russ.). DOI: 10.14529/ ling160213

8. Tartt D. The Secret History. London, 1992. $630 \mathrm{p}$.

9. Tartt D. The Secret History. Kharkiv, 2017. 560 p.

10. Edemariam A. The Guardian (2004). URL: https://www.theguardian.com/books/2004/oct/02/featuresreviews. guardianreview37.

УДК 316.772 .2

DOI https://doi.org/10.32782/tps2663-4880/2021.15.30

\section{ВЕРБАЛЬНІ ЗНАКИ КОМПЛІМЕНТУ В КООПЕРАТИВНІЙ СТРАТЕГІЇ В РАМКАХ ОФІЦЙНО-ДІЛОВОГО ДИСКУРСУ}

\section{VERBAL SIGNS OF A COMPLIMENT IN A COOPERATIVE STRATEGY WITHIN THE OFFICIAL BUSINESS DISCOURSE}

\author{
Рейда О.А., \\ orcid.org/0000-0003-2227-7994 \\ старший викладач кафедри іноземних мов \\ Білочерківського національного аграрного університету \\ Івлсва К.С., \\ orcid.org/0000-0002-9539-4086 \\ стариий викладач кафедри інтелектуальних комп 'ютерних систем \\ Національного технічного університету «Харківський політехнічний інститут» \\ Гулієва Д.О., \\ orcid.org/0000-0001-8310-745X \\ кандидат філологічних наук, \\ доцент кафедри інтелектуальних комп'ютерних систем \\ Національного технічного університету «Харківський політехнічний інститут»
}

\footnotetext{
У статті наведено опис компліментів та їх вербальних знаків у англійській мові. Окремо проаналізовано явище компліментів в кооперативній стратегії в рамках офріційної комунікації на матеріалі англо-американського кінодискурсу (комедія-драма "The Intern").

Визначено основні критерії класифікації компліментів та наголошено на тому, що окремим аспектом вивчення компліментів $є$ зіставний аналіз комунікативного акту в різних лінгвокультурах (українській та англійській, російській та англійській).
} 